\title{
Perinatal Outcomes in Pregnant Women Users of Illegal Drugs
}

\section{Resultados perinatais em gestantes usuárias de drogas ilícitas}

\author{
Tenilson Amaral Oliveira ${ }^{1,2}$ Ana Aparecida Sanches Bersusa ${ }^{3}$ Tatiana Fiorelli dos Santos ${ }^{1}$ \\ Márcia Maria Auxiliadora de Aquino ${ }^{1,2}$ Corintio Mariani Neto ${ }^{1,2}$ \\ ${ }^{1}$ Hospital Maternidade Leonor Mendes de Barros, Medical School, \\ São Paulo, SP, Brazil \\ 2 Medical School, Universidade Cidade de São Paulo, São Paulo, \\ SP, Brazil \\ Address for correspondence Tenilson Amaral Oliveira, Hospital \\ Maternidade Leonor Mendes de Barros, Av. Celso Garcia 2477 - \\ Belenzinho 03015-000 - São Paulo, SP, Brazil \\ (e-mail: tenilson@uol.com.br).
}

3 Division of Nursing, Hospital Maternidade Leonor Mendes de Barros,

\begin{abstract}
Objective The purpose of this study was to evaluate the perinatal outcomes in pregnant women who use illicit drugs.

Methods A retrospective observational study of patients who, at the time of delivery, were sent to or who spontaneously sought a public maternity hospital in the eastern area of São Paulo city. We compared the perinatal outcomes of two distinct groups of pregnant women - illicit drugs users and non-users - that gave birth in the same period and analyzed the obstetric and neonatal variables. We used Student's $t$-test to calculate the averages among the groups, and the Chi-square test or Fisher's exact test to compare categorical data from each group.

Results We analyzed 166 women ( 83 users and 83 non-users) in both groups with a mean of age of 26 years. Ninety-five percent of the drug users would use crack or pure

\section{Keywords}

- crack cocaine

- cocaine

- pregnancy complications

- congenital syphilis

- prenatal care cocaine alone or associated with other psychoactive substances during pregnancy. Approximately half of the users group made no prenatal visit, compared with $2.4 \%$ in the non-users group $(p<0.001)$. Low birth weight $(2,620 \mathrm{~g}$ versus $3,333 \mathrm{~g}$ on average, $p<0.001)$ and maternal syphilis $(15.7 \%$ versus $0 \%, p<0.001)$ were associated with the use of these illicit drugs.

Conclusions The use of illicit drugs, mainly crack cocaine, represents an important perinatal risk. Any medical intervention in this population should combine adherence to prenatal care with strategies for reducing maternal exposure to illicit drugs.
\end{abstract}

received

August 18, 2015

accepted

December 4, 2015

published online

April 18, 2016
DOI http://dx.doi.org/

10.1055/s-0036-1580710. ISSN $0100-7203$.
Copyright $@ 2016$ by Thieme Publicações License terms

Ltda, Rio de Janeiro, Brazil

(c) (1) $\odot \circledast$ 


\section{Resumo}

\author{
Palavras-chave \\ - crack \\ - cocaína \\ - complicações na \\ gravidez \\ - sífilis congênita \\ - cuidado pré-natal
}

Objetivo Avaliar o resultado perinatal das gestantes usuárias de drogas ilícitas. Métodos: estudo retrospectivo, observacional de gestantes que procuraram espontaneamente ou foram encaminhadas no momento do parto para maternidade pública na Zona Leste do município de São Paulo. Comparamos os resultados perinatais do grupo de gestantes que utilizaram drogas ilícitas com um grupo de não usuárias, que tiveram o parto no mesmo período, para análise das variáveis obstétricas e neonatais. O teste $t$ de Student foi utilizado para cálculo das médias entre os grupos. O teste do Quiquadrado e exato de Fisher foram usados para comparação de dados categóricos de cada grupo.

Resultados Avaliamos 166 mulheres (83 usuárias e 83 não usuárias), com uma média de idade de 26 anos, em ambos os grupos. A cocaína pura ou sob a forma de crack foi utilizada isolada ou associada a outras substâncias psicoativas em $95 \%$ das que referiram uso de drogas durante a gravidez. Aproximadamente metade das usuárias não teve nenhuma consulta pré-natal enquanto que entre as não usuárias apenas $2,4 \%$ não tiveram consultas de pré-natal $(p<0,001)$. A menor média de peso ao nascer (2620 g versus $3333 \mathrm{~g}, p<0,001)$ e a presença de sífilis materna $(15,7 \%$ versus $0 \%$, $p<0,001)$ foram associados ao uso de drogas ilícitas.

Conclusões $\mathrm{O}$ uso de drogas ilícitas, principalmente crack, é um fator de risco perinatal significativo. Qualquer abordagem médica nesse grupo de gestantes usuárias de drogas ilícitas deve combinar a adesão ao pré-natal com estratégias voltadas à redução da exposição materna a essas substâncias.

\section{Introduction}

The use of illicit drugs during pregnancy has become an alarming public health problem worldwide. In the United States, the prevalence of illicit drug use during pregnancy in women aged between 15 and 44 years who reported the use of these substances in the last 30 days reached $4.4 \%{ }^{1}$ In Europe, a study that analyzed illicit substances in the meconium indicated that $7.9 \%$ of pregnant women had been exposed to psychoactive substances. ${ }^{2}$ In $4.4 \%$, the usage was exclusively of cocaine. ${ }^{2}$ In Brazil, there are few studies on the topic. However, one analyzed the patients of the 25 Basic Health Units of the region of Maringá in the state of Paraná and concluded that prevalence of illicit drug use was $1.5 \%$ in pregnant women. ${ }^{3}$ Another hospitalbased study revealed that the prevalence of prenatal exposure to cocaine exclusively in a sample of newborns in a general university hospital, either through the assessment of drugs in the meconium or through maternal interview, reached $4.6 \%{ }^{4}$

The use of illicit drugs during pregnancy is associated with the occurrence of sexually transmitted diseases (STDs), such as syphilis, AIDS, and hepatitis. ${ }^{5}$ The consumption of cocaine, specifically, elevates the risk of maternal and fetal complications, such as placental abruption, emergence of meconium, early break of ovular membranes, short stature, and low weight at birth, besides genitourinary and abdominal wall abnormalities. These effects are independent of the use of other types of psychoactive substances. ${ }^{6}$

In general, illicit drugs act on the maternal cardiovascular system, causing adrenergic hyperstimulation and
vasoconstriction.There is an increase in heart rate and maternal blood pressure with consequent decreased blood flow to the uterus and risk of fetal growth restriction. ${ }^{7}$ However, the unfavorable fetal and perinatal outcomes of illicit drug use are still subject of controversy in the literature, since other factors associated with the use of these substances can contribute to these results. These factors include social and behavioral aspects, such as smoking, alcoholism, lack of prenatal care, and low socioeconomic status. ${ }^{8}$ Thus, drug addiction during pregnancy poses a new challenge to obstetric care, and perinatal analysis of illicit drugs users can contribute to establish the best professional approach for this specific group of women.

\section{Methods}

We developed a retrospective, observational study that included pregnant women users of illicit drugs who spontaneously sought or were forwarded at birth to the Hospital e Maternidade Leonor Mendes de Barros (HMLMB), a public maternity state hospital, located in the eastern area of São Paulo, Brazil. This is a reference hospital for high-risk pregnancies and addicted pregnant women. We analyzed the obstetric and neonatal complications of a group of pregnant women who used illicit drugs and compared the data against a group of non-users who had given birth in the same period - from January 14, 2011, to October 31, 2013.

The inclusion criterion was the record of illicit drug in anamnesis. Upon hospital admission, we asked all patients about their use of illicit drugs such as marijuana, crack, cocaine, besides the time of use and the last dose. Pregnant 
women with less than 22 weeks of pregnancy were excluded from the study.

The analyzed sample comprised 83 women who used illicit drugs and 83 women who did not report using illicit drugs; both types of women were hospitalized during the study period. For each case of a pregnant woman who used illicit drugs included in the study, we collected information on a pregnant woman who did not use illicit drugs, preferably on the same date of hospitalization, applying the same inclusion criteria.

To obtain systematized data in the medical records, we created an instrument. This instrument identified the demographic variables and perinatal factors, such as age, number of previous pregnancies, frequency to prenatal care, number of visits, scrutiny of examinations results for Venereal Disease Research Laboratory (VDRL) and Human Immunodeficiency Virus (anti-HIV), obstetric and neonatal intercurrences, type of delivery, and weight of the newborn.

We entered the collected data into Microsoft Office Excel 10 spreadsheets and used the Statistical Package for the Social Sciences (SPSS) program for Windows 21 for the statistical analysis. We used the Chi-square test $\left(x^{2}\right)$ and Fischer exact test to compare the categorical data of each group, with a significance level of $5 \%(p<0.05)$. We used the Student's $t$-test to assess the differences between the means of demographic data and the perinatal outcomes. The Research Ethics Committee of the Hospital Maternidade Leonor Mendes de Barros (HMLMB) approved this study under protocol CAAE 44804415.7.0000.0063.

\section{Results}

The prevalence of pregnant illicit drug users hospitalized in the HMLMB was $1.9 \%$ of the total number attending during the study period. - Table 1 describes the illicit drugs used by the users group. We observed that crack or pure cocaine, alone or together with other drugs, was the most common substance, consumed by $95 \%$ of users.

The drug addiction interval ranged from four months to 10 years among users. The interval between prior drug use and entry in the maternity ward was highly variable: 24

Table 1 List of illicit drugs referred to by pregnant women at the time of hospitalization at a public maternity hospital in São Paulo

\begin{tabular}{|l|l|l|}
\hline Drugs & N & $\%$ \\
\hline Crack & 29 & 35 \\
\hline Cocaine & 24 & 29 \\
\hline Crack + Cocaine & 5 & 6 \\
\hline Cocaine + Marijuana & 9 & 10.8 \\
\hline Crack + Marijuana & 8 & 9.6 \\
\hline Crack + Cocaine + Marijuana & 4 & 4.8 \\
\hline Marijuana & 4 & 4.8 \\
\hline Total & 83 & 100 \\
\hline
\end{tabular}

patients (28.9\%) said they had used drugs on the same day or the day before, 13 patients (15.7\%) in the last week, and five of the patients (6.0\%) in the last month. Approximately 17 patients $(20.5 \%)$ said they have used illicit drugs for the last time more than a month ago, while 24 patients $(28.9 \%$ ) could not mention when they used the drugs for the last time during pregnancy.

As shown in - Table 2, mean age was similar between the groups. Primiparous patients were more frequent in the nonusers group, while the users group had a higher number of previous births. We also observed a significant difference in smokers between the groups ( $\boldsymbol{- T a b l e ~} \mathbf{2}$ ).

The gestational age during hospital stay indicated by the women ranged from 29.1 to 43 weeks in both groups; however, it was not possible to compare between the groups, because 23 patients (27.7\%) from the pregnant drug users group could not mention the date of their last menstruation. The number of women who attended prenatal care was lower in the users group when compared with the non-users group (42 versus 81, odds ratio 39.5; 95\% CI 9.1 - 171.5), as seen in - Table 2 . Among those who attended prenatal care in the users group, only 11 women (26.2\%) attended more than six consultations whereas this occurred in 45 pregnant women (55.6\%) of the control group (non-users group).

The pregnant users arrived at the maternity unit in different ways: $54.2 \%$ of them came spontaneously to give birth in our service; $28.3 \%$ were brought by the Emergency Medical Service (Serviço de Atendimento Médico de Urgência - SAMU), and $17.5 \%$ were referred by the Alcohol and Drug Referral Center (Centro de Referência de Álcool e Droga CRATOD) or by the Psychosocial Attention Center (Centro de Atenção Psicosocial - CAPS). In the non-users group, all arrived at the hospital by their own means.

During the obstetric examination upon entry in our service, we found 24 cases of premature rupture of membranes (28.9\%), 7 cases (8.4\%) of gestational hypertension, and 2 patients $(2.4 \%)$ arrived with placental abruption within the users group. - Table 3 presents other perinatal outcomes. The rate of cesarean section was similar between the two groups. The average birth weight was significantly lower in the users group. We found 35 newborns (42.2\%) presenting less than 2,500 g weight at birth in this group and only three newborns (3.6\%) in the non-users group $(p<0.001)$. There were no significant differences between the groups regarding the need for ventilator support, congenital malformations, or neonatal sepsis. No fetal or neonatal deaths were observed in either group.

We found 13 cases of maternal syphilis in the illicit drugs users group only ( - Table 3 ). Of these, 11 were consumers of crack and two of cocaine. Six of these pregnant women did not attend prenatal care and seven did not undergo treatment for syphilis before hospitalization. We observed eight newborns $(8 / 13)$ of this group with low birth weight. The vertical transmission of syphilis occurred in $30.8 \%$ (4/13) of those cases.

From the users group, soon after birth, seven newborns (8.4\%) were referred to the neonatal intensive care unit (ICU), $46(55.4 \%)$ to the neonatal intermediate care unit, and 30 
Table 2 Sociodemographic and behavioral characteristics of pregnant women who are users and non-users of illicit drug

\begin{tabular}{|l|l|l|l|}
\hline Characteristics & $\begin{array}{l}\text { Users Group } \\
(\boldsymbol{n}=\mathbf{8 3 )}\end{array}$ & $\begin{array}{l}\text { Non-users Group } \\
(\boldsymbol{n}=\mathbf{8 3 )}\end{array}$ & $\boldsymbol{p}$ value \\
\hline Age (mean years) & $26.6 \pm 6.7$ & $26.4 \pm 6.6$ & 0.95 \\
\hline Nulliparous (\%) & $18(21.7)$ & $33(39.8)$ & 0.01 \\
\hline White skin (\%) & $33(39.8)$ & $36(43.4)$ & 0.63 \\
\hline Pre-natal (\%) & $42(50.6)$ & $81(97.6)$ & $<0.001$ \\
\hline Smoker (\%) & $60(72.3)$ & $8(9.6)$ & $<0.001$ \\
\hline
\end{tabular}

The $p$ value was considered statistically significant when lower than $5 \%$.

Table 3 Perinatal outcomes of illicit drug users and non-users

\begin{tabular}{|l|l|l|l|}
\hline Perinatal outcome & $\begin{array}{l}\text { User Group } \\
(\boldsymbol{n}=\mathbf{8 3})\end{array}$ & $\begin{array}{l}\text { Non-user Group } \\
(\boldsymbol{n}=\mathbf{8 3 )}\end{array}$ & $\boldsymbol{p}$ value \\
\hline Cesarean delivery (\%) & $24(31.6)$ & $21(33.3)$ & 0.60 \\
\hline Average birth weight (grams) & $2620 \pm 510$ & $3333 \pm 561$ & $<0.001$ \\
\hline Maternal syphilis (\%) & $13(15.7)$ & 0 & $<0.001$ \\
\hline Major congenital malformations (\%) & $1(1.2)$ & $1(1.2)$ & 1.0 \\
\hline Neonatal ventilator support (\%) & $12(14.5)$ & $13(15.7)$ & 0.82 \\
\hline Neonatal sepsis (\%) & $6(7.2)$ & $3(3.6)$ & 0.30 \\
\hline Congenital syphilis (\%) & $4(4.8)$ & $0(-)$ & 0.12 \\
\hline
\end{tabular}

The $p$ value was considered statistically significant when lower than $5 \%$.

(36.2\%) to the general maternity ward. They remained in the hospital for a period of 2 to 36 days, while half of them (50.8\%) remaining hospitalized for more than 10 days, the majority waiting for judicial decision on the responsibility for their care. In the non-users group, 70 newborns (84.3\%) were referred to the general maternity ward, and 13 (15.7\%) to the neonatal ICU and/or the intermediate care unit. With regard to breastfeeding, 44 women (53\%) of the users group breastfed their babies in the maternity. The rest of the group did not breastfeed, mainly by medical indication, due to the risk to the newborn of recent use of illicit drugs.

At hospital discharge, 73 women (88\%) in the illicit drug users group went from the maternity to their homes, 3 (3.6\%) returned to a homeless situation, $2(2.4 \%)$ were sent to Psychosocial Support Centers (CAPs), and in 5 (6.0\%) cases, there were no records on the medical records of destination after discharge due to hospital evasion. Of the newborns, 57 (68.7\%) went home with the mother and or family and 26 (31.3\%) were referred to shelters. All women non-users of drugs went to their homes along with the newborns, because there was no social risk.

\section{Discussion}

Our study reveals that pregnant women using illicit drugs frequently used crack and cocaine, either pure or together with other drugs such as marijuana. The preference for crack was mainly due to its low cost. Crack rock is produced using different chemical substances, which makes it even more dangerous for mothers and newborns. ${ }^{9}$ Data from the Brazilian Report on Drugs ${ }^{10}$ show that, in the southeastern region of Brazil, $24.5 \%$ of the population has already used illicit drugs at some point in their lives. Among the aforementioned drugs, marijuana (6.9\%) and solvents (5.8\%) are noteworthy. Cocaine was used by $2.3 \%$ and crack by $0.4 \%$ of the population. These data are in agreement with the prevalence found in our study, with the exception of marijuana, which is considered the most commonly used illicit drug during pregnancy. ${ }^{11}$ The low prevalence of this drug evidenced by our study was possibly due to the forwarding of the most serious cases of drug addiction to our maternity, a reference establishment for this type of care.

As observed during our study, the lack of prenatal care affects the perinatal outcome because basic information for obstetric conduct, such as gestational age, was not obtained from a significant percentage of patients who were illicit drugs users.

We can infer that the high prevalence of congenital syphilis in newborns of pregnant women using illicit drugs can be directly associated with the lack of prenatal care, because syphilis is a disease that requires compulsory detection and treatment during pregnancy. The presence of one case of syphilis in every six pregnant women using illicit drugs attending our maternity reinforces the absence or the inadequacy of basic care for this vulnerable group of women. All these factors influence the increase in the vertical transmissibility of syphilis in this study. In the Southeastern region of Brazil, the coverage rate of syphilis testing revealed a frequency of $1.03 \%{ }^{12}$ among women during prenatal care 
with a rate of detection of congenital syphilis of 3.6 cases per 1000 live births in 2012. ${ }^{13}$

The consequences of drug exposure during pregnancy depend on the type of drugs, duration of use, administration route, quantity used, and duration of use before delivery. ${ }^{14}$ The use of cocaine can result in placental infarctions or hemorrhages in any gestational period. ${ }^{15,16}$ We observed that half of the users reported drug use near delivery, which may have contributed to the occurrence of placental abruption, premature delivery, and hypertensive syndromes. The drug-induced vasoconstriction also leads to placental flow reduction, with significant repercussions on fetal growth and weight. It is likely that cocaine contributed significantly to restrict the growth of newborns in pregnant women because the prevalence of newborns weighing less than 2,500 $\mathrm{g}$ was higher in this group when compared with that in the non-users group. In a meta-analysis, Gouin et $\mathrm{al}^{17}$ analyzed several studies that included women who used cocaine during pregnancy. The results identified the outcomes of prematurity and low birth weight as two highly prevalent characteristics in 31 studies included in their review. Our results are in agreement with this review.

Although cocaine is considered a teratogenic drug,,${ }^{15,18}$ there were no differences between the two groups with regard to the presence of congenital malformations in newborns. However, there is no consistent scientific evidence on the role of cocaine as a major teratogen. A longitudinal cohort prospective study ${ }^{19}$ examined 272 children of crack-cocaine users and found no increase in the number or pattern of congenital defects. Since few studies have assessed the dosage or fetal exposure to cocaine during pregnancy, it is difficult to estimate the risk of fetal malformation associated with its use.

Because of the risk associated with the recent use of drugs and the difficulties the mother faces when caring for the newborn, they were frequently forwarded upon delivery to the neonatal intermediate care unit or to the neonatal ICU.

The majority of illicit drugs are liposoluble and frequently present in milk. All these provide rapid passage of the consumed drugs to the bloodstream of the newborn, making it susceptible to adverse effects, including intoxication and withdrawal symptoms. ${ }^{20}$ In our service, we discuss the indication of breastfeeding with a multidisciplinary team and, when there is possible recent use of the substance, we contraindicate breastfeeding for the first 24 hours. After this period, the case is re-evaluated to decide breastfeeding. For this reason, nearly half of the newborns from the group of user mothers were no longer breastfed during the hospital stay.

Our study confirms the difficulties of prenatal care in the group of pregnant women using illicit drugs and the perinatal complications because of lack of care. We believe that the of health care services must provide specific care to this population when assessing the future impact of illicit drug use in pregnancy, due to not only the medical complications, but also the social problems. In our study, we observed that almost a third of the newborns were forwarded to social shelters, awaiting judicial proceedings on their future. This scenario should motivate the health teams in the elaboration of studies and guidelines to better assist this vulnerable population. We believe that the best medical intervention in pregnant women users of illicit drugs must combine adherence to prenatal care with strategies to reduce maternal exposure to illicit drugs.

\section{References}

1 U.S. Department of Health and Human Services. Substance Abuse and Mental Health Services Administration. Center for Behavioral Health Statistics and Quality [Internet]. Results from the 2013 National Survey on Drug Use and Health: summary of national findings. RockvilleSubstance Abuse and Mental Health Services Administration2014. (NSDUH Series H-48, HHS Publication No. (SMA) 14-4863). Accessed November 8, 2015. Available from: http://www.samhsa.gov/data/sites/default/files/ NSDUHresultsPDFWHTML2013/Web/NSDUHresults2013.pdf

2 Pichini S, Puig C, Zuccaro P, et al. Assessment of exposure to opiates and cocaine during pregnancy in a Mediterranean city: preliminary results of the "Meconium Project". Forensic Sci Int 2005;153(1):59-65

3 Kassada DS, Marcon SS, Pagliarani MA, Rossi RM. Prevalência do uso de drogas de abuso por gestantes. Acta Paul Enferm. 2013; 26(5):467-471

4 Cunha GB, Rotta NT, Silva AR, et al. Prevalence of prenatal exposure to cocaine in a sample of newborns from a university teaching hospital. J Pediatr (Rio J) 2001;77(5):369-373

5 Cunningham FG, Leveno KJ, Bloom SL, Hauth JC, Rouse DJ, Spong CY. Obstetrícia de Williams. 23a edição. Porto Alegre: McGrawHill; 2012. Doenças infecciosas; p. 1210-34

6 Botelho APM, Rocha RC, Melo VH. Uso e dependência de cocaína/crack na gestação, parto e puerpério. Femina 2013; 41(1):23-32

7 Cembranelli E, Campos LRF, Portella M, Abreu PVC, Salomão PC, Monteiro DLM. Consequências do uso de cocaína e metanfetamina durante a gravidez. Femina 2012;40(5):241-245

8 Malta M, Bastos FI, Monteiro M. Manejo do paciente usuário de drogas vivendo com HIV/AIDS. In: Alarcon S, Jorge MAS, organizadores. Álcool e outras drogas: diálogos sobre um malestar contemporâneo. Rio de Janeiro: Editora Fiocruz; 2012: 239-64

9 Conselho Federal de Medicina [Internet]. Diretrizes gerais médicas para assistência integral ao dependente do uso da crack. Brasília (DF): Conselho Federal de Medicina; 2011. Accessed June 17, 2014. Available from: http://www.sbp.com.br/pdfs/diretrizes-medicas-integral-crack-cfm.pdf

10 Brasil. Presidência da República. Secretaria Nacional de Políticas sobre Drogas [Internet]. Relatório brasileiro sobre drogas. Brasília (DF): SENAD; 2009. Accessed November 7, 2014. Available from: http://www.unisite.ms.gov.br/unisite/controle/ShowFile.php? id $=100977$

11 American College of Obstetricians and Gynecologists Committee on Obstetric Practice. Committee Opinion No. 637: marijuana use during pregnancy and lactation. Obstet Gynecol 2015;126(1): 234-238

12 Domingues RM, Szwarcwald CL, Souza Junior PR, Leal MdoC. Prevalence of syphilis in pregnancy and prenatal syphilis testing in Brazil: birth in Brazil study. Rev Saude Publica 2014;48(5): 766-774

13 Boletim Epidemiológico Sífilis. Brasília (DF): Ministério da Saúde. 2012;1(1) Accessed November 5, 2014. Available from: http:// www.aids.gov.br/sites/default/files/anexos/publicacao/2012/ 52537/boletim_sifilis_2012_pdf_26676.pdf 
188 Perinatal Outcomes in Pregnant Women Users of Illegal Drugs Oliveira et al.

14 Kuczkowski KM. The effects of drug abuse on pregnancy. Curr Opin Obstet Gynecol 2007;19(6):578-585

15 Cunningham FG, Leveno KJ, Bloom SL, Hauth JC, Rouse DJ, Spong CY. Obstetrícia de Williams. 23a ed. Teratologia e medicamentos que acometem o feto. Porto alegre: McGraw-Hill; 2012:327-8

16 Barreto LGG, Packer MP. Dependência química na gravidez [dissertation]. São Paulo: Universidade Federal de São Paulo (UNIFESP); 2007. Accessed June 26, 2014. Available from: http://www.uniad.org.br/desenvolvimento/images/stories/arquivos/TCC/Dependencia_Quimica_Na_Gravidez.pdf

17 Gouin K, Murphy K, Shah PS; Knowledge Synthesis group on Determinants of Low Birth Weight and Preterm Births. Effects of cocaine use during pregnancy on low birthweight and preterm birth: systematic review and metaanalyses. Am J Obstet Gynecol 2011;204(4):340.e1-340.e12

18 Wells BG. Pregnancy and lactation: therapeutic considerations. In: DiPiro JT, Schwinghammer TL, DiPiro CV. Pharmacotherapy handbook. 2nd Ed. New York: Appleton \& Lange; 2001:353-62

19 Behnke M, Eyler FD, Garvan CW, Wobie K. The search for congenital malformations in newborns with fetal cocaine exposure. Pediatrics 2001;107(5):E74

20 Day E, George S. Management of drug misuse in pregnancy. Adv Psychiatr Treat 2005;11(4):253-261 